NBER WORKING PAPERS SERIES

\title{
THE EFFECT OF THE MINIMUM WAGE ON THE FAST FOOD INDUSTRY
}

Lawrence F. Katz

Alan B. Krueger

Working Paper No. 3997

\section{NATIONAL BUREAU OF ECONOMIC RESEARCH \\ 1050 Massachusetts Avenue \\ Cambridge, MA 02138 \\ February 1992}

The authors are grateful to Colleen Frial and Kainan Tang for expert research assistance, and to the University of Wisconsin, Institute for Research on Poverty for financial support. They also acknowledge helpful comments from David Card, Henry Farber, Richard Lester, and Olivia Mitchell. The data used in this paper will be supplied to other researchers on request to Alan B. Krueger, Department of Economics, Princeton University, Princeton, NJ, 08544. This paper is part of NBER's research program in Labor Studies. Any opinions expressed are those of the authors and not those of the National Bureau of Economic Research. 
NBER Working Paper \#3997

February 1992

\title{
THE EFFECT OF THE MINIMUM WAGE ON THE FAST FOOD INDUSTRY
}

\begin{abstract}
Using data from a longitudinal survey of fast food restaurants in Texas, the authors examine the impact of recent changes in the federal minimum wage on a low-wage labor market. The authors draw four main conclusions. First, the survey results indicate that less than 5 percent of fast food restaurants use the new youth subminimum wage even though the vast majority paid a starting wage below the new hourly minimum wage immediately before the new minimum went into effect. Second, although some restaurants increased wages by an amount exceeding that necessary to comply with higher minimum wages in both 1990 and 1991, recent increases in the federal minimum wage have greatly compressed the distribution of starting wages in the Texas fast food industry. Third, employment increased relatively in those firms likely to have been most affected by the 1991 minimum wage increase. Fourth, changes in the prices of meals appear to be unrelated to mandated wage changes. These employment and price changes do not seem consistent with conventional views of the effects of increases in a binding minimum wage.
\end{abstract}

Lawrence F. Katz

Department of Economics

Harvard University

Cambridge, MA 02138

and NBER

\author{
Alan B. Krueger \\ Department of Economics \\ Princeton University \\ Princeton, NJ 08544 \\ and NBER
}


After nearly a decade without change, legislation increased the federal minimum wage from $\$ 3.35$ to $\$ 3.80$ on April 1,1990 , and increased it again to $\$ 4.25$ on April 1, 1991. The amendments to the Fair Labor Standards Act (FLSA) further permitted employers' to pay teenage workers a subminimum or "training" wage equal to $85 \%$ of the minimum wage. Employers may currently pay teenage workers as little as $\$ 3.61$ per hour for up to 6 months under these subminimum wage provisions. How have these changes to the minimum wage affected the low-wage labor market? This paper examines the impact of recent changes in the federal minimum wage on the fast food industry.

Five main questions are raised in this paper. First, what is the utilization rate of the teenage subminimum wage? Second, what determines whether a restaurant will utilize the subminimum wage? Third, how has the minimum wage affected wage dispersion? Fourth, what effect has the increase in the minimum wage had on the level of employment at firms affected by the increase? Fifth, how has the minimum wage increase affected the price of fast food items?

To answer these questions we conducted a longitudinal survey of fast food restaurants in Texas in December 1990 and July/August 1991. The Texas economy experienced a prolonged downturn starting in the mid-1980s that continued through 1991. The weak labor market in Texas should have magnified the impact of the minimum wage. Moreover, the minimum wage is a significant constraint on fast food establishments. Our survey of Texas fast food restaurants finds that one-third of restaurants started workers at the minimum wage prior to the April 1990 minimum wage increase, whereas half of 
restaurants started workers at the minimum wage shortly after the 1990 minimum wage increase, and over three-quarters of restaurants started workers at the minimum wage shortly after the April 1991 increase. Finally, the fast food industry is generally regarded as a highly competitive industry, with little firm attachment and high labor turnover. Thus, the fast food industry offers a near ideal market to test the predictions of the textbook model of the minimum wage.

\section{Texas Fast Food Restaurant Survey Design}

To study the impact of recent changes in the minimum wage on a labor market where we would expect the minimum wage to have a large impact, we conducted a survey of fast food restaurants in Texas. We selected Texas because it is a large state with relatively many low-paid workers. In 1989, for example, the average hourly wage rate of retail trade workers in Texas was $\$ 5.85$, compared to a national average of $\$ 6.52$. For teenage workers, the average wage in Texas in 1989 was $\$ 4.19$ compared to $\$ 4.61$ nationwide, and $37.6 \%$ of teenage workers in Texas were paid between $\$ 3.35$ and $\$ 3.79$ per hour, compared to $25.7 \%$ nationwide. ${ }^{1}$ Furthermore, Texas does not have a state minimum wage law that would override the FLSA. ${ }^{2}$

Moreover, the fast food industry is a low-wage industry even within retail trade. The industry has lobbied against increases in the minimum wage and has 
been a staunch supporter of a subminimum wage for youths (Bureau of National Affairs, 1985). And the fact that the fast food industry has extremely high turnover, and hires many first-time workers, makes it more likely that fast food restaurants can take advantage of the youth subminimum. ${ }^{3}$

Figure 1 outlines the timing of our surveys, and of changes in the minimum wage. In 1990 we designed an initial questionnaire to collect retrospective (preminimum wage increase) and current information on starting wages, as well as information on the utilization of the new subminimum wage and on nonwage responses to the minimum wage. This survey was administered in December 1990. In 1991 we revised the questionnaire, retaining most of the questions from the original survey, and adding new questions on prices of standard goods at the restaurants and wages of workers already at the firm. The second questionnaire was administered between July 8, 1991 and August 2, 1991.4

We conducted the survey as follows. We first collected the phone numbers of every Burger King, Wendy's, and Kentucky Fried Chicken outlet listed in the Yellow Pages of the metropolitan phone books for Texas for January $1990 .^{5}$ We then drew a systematic sample consisting of every other phone number listed in the Yellow Pages. After deleting duplicate numbers, disconnected numbers, and wrong numbers, this yielded a universe of 294 potential observations. We then attempted to interview the manager or assistant manager of these restaurants by phone between December 12 and December 18, 1990. If a restaurant did not respond on the first call, we called back as 

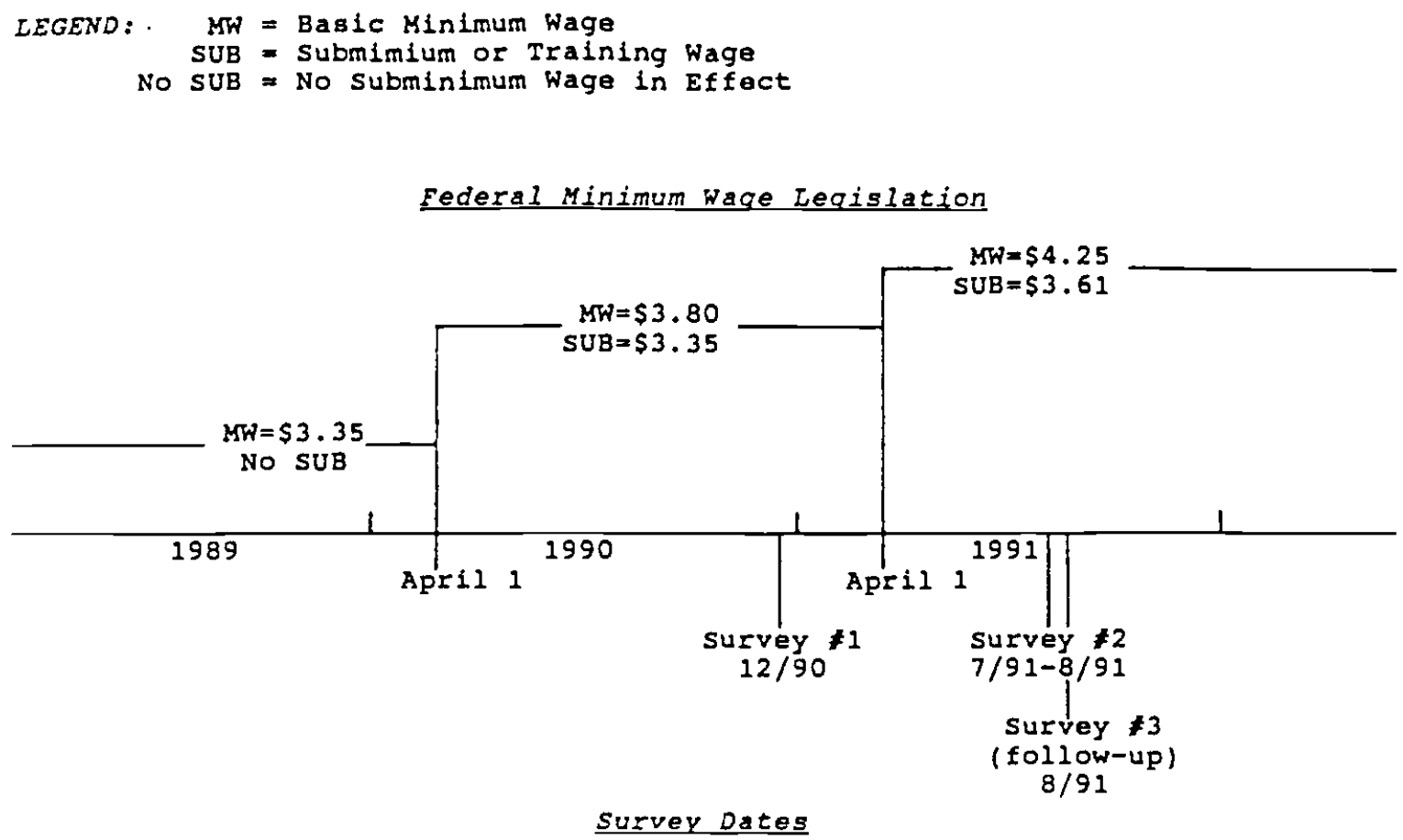

FIGURE 1:

Chronology of Changes in Federal Minimum Wage Legislation and of Implementation of Texas Fast Food Restaurant Surveys 
many as two more times to try to elicit a response. We obtained a total of 167 responses, for a response rate of 57 percent from the 1990 survey. ${ }^{7}$

For the follow-up survey we attempted to interview every restaurant listed in the 1990 phone books for Texas, including those that were originally sampled in 1990 and those that were not. A total of 330 restaurants were interviewed between July and August 1991 in the second wave of the survey; 110 of these firms were previously interviewed in the first wave of the survey. The overall response rate in the second wave of the survey was $56 \%$, whereas the response rate was $66 \%$ for the subset of firms that responded in the first wave of the survey. ${ }^{8}$ We collected additional information about the local labor market in which each restaurant was located (e.g., the unemployment rate and size of the city) using the County and City Data Book, 1988.

To assess the reliability of responses to key questions on the survey, we randomly selected 30 restaurants that responded in the second wave of the survey, and re-interviewed them in August 1991. The sampled firms were asked the same set of questions regarding wages, prices, and employment that they were asked previously. We then calculated the correlation between responses on the original survey and on this re-interview survey. These correlations are an estimate of the ratio of the true variance of the variable to the total reported variance, under the assumption that reporting errors are uncorrelated with each other and with the true variable in each measurement. The correlations were generally in the .70 to .80 range. For example, the correlation between the two 
measurements was .76 for starting pay, .76 for log employment, .65 for the price of french fries, .72 for the price of soda, .85 for the percent of workers who are black, and .93 for the percent of workers who are hispanic. Table 1 presents a cross-tab of the starting wage for part-time workers of sampled restaurants before and after the April 1990 and April 1991 increases in the minimum wage. ${ }^{9}$ The table indicates that $71.4 \%$ of these restaurants were compelled to increase their starting wage by the 1990 rise in the minimum wage from $\$ 3.35$ to $\$ 3.80$. Furthermore, one-third of the restaurants moved their starting wage from exactly the old minimum to exactly the new minimum. In December $1990,47 \%$ of restaurants were starting workers at exactly the minimum wage $(\$ 3.80)$.

The April 1991 increase in the minimum from $\$ 3.80$ to $\$ 4.25$ had an even larger effect on restaurant wages. Some $95 \%$ of restaurants were forced to increase their starting wage by the 1990 increase in the minimum wage, and $75.8 \%$ of restaurants paid new hires exactly the minimum wage $(\$ 4.25)$ in the summer of 1991. Notice also that the fraction of restaurants that paid exactly the old minimum wage $(\$ 3.80)$ was slightly higher in July/August 1991 than in December 1990 (47\% vs. $55.4 \%$ ). This finding suggests that the labor market in Texas was slipping before the 1991 higher minimum wage took effect, perhaps due to the onset of the 1991 recession. The increase in the minimum wage in 1991 would be especially binding if the Texas labor market would have continued to decline. These tabulations indicate that our survey has identified 
Table 1: Cross-tabulations of Starting Wage for Before and After Two Minimum Wage Increases

A. Minimum Wage Increase from $\$ 3.35$ to $\$ 3.80$, April 1,1990

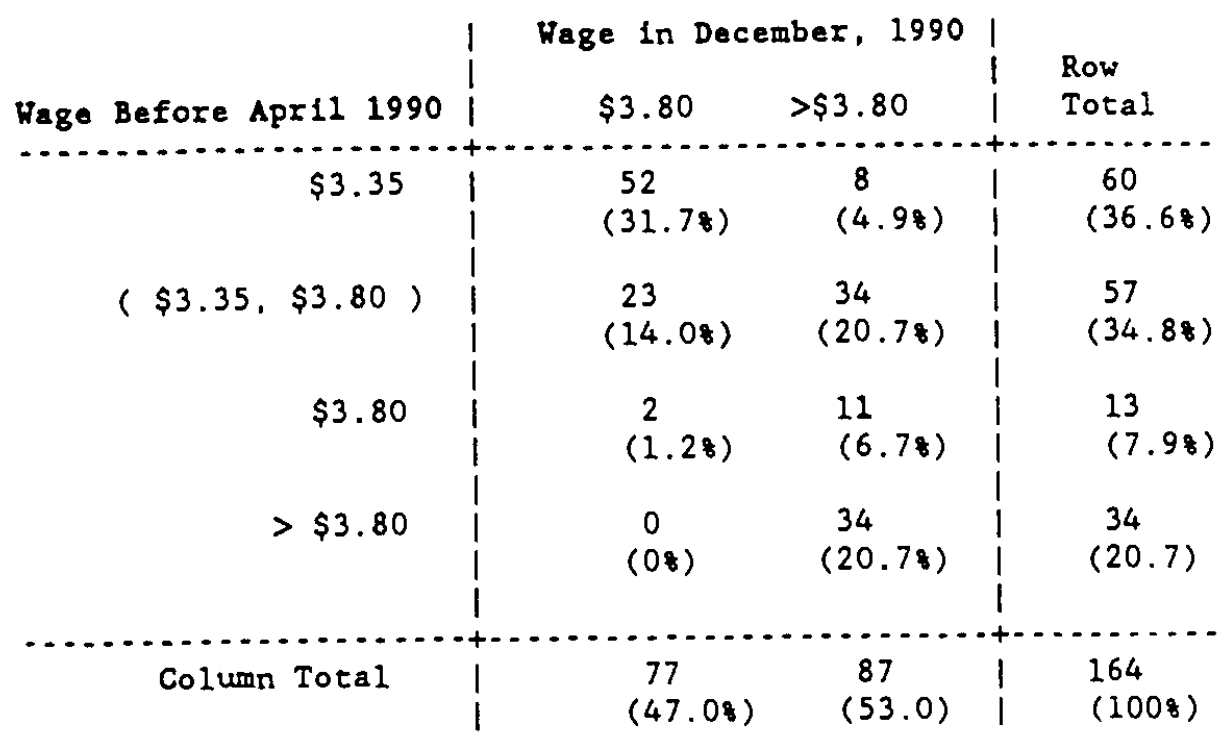

B. Minimum Wage Increase from $\$ 3.80$ to $\$ 4.25$, April 1,1991

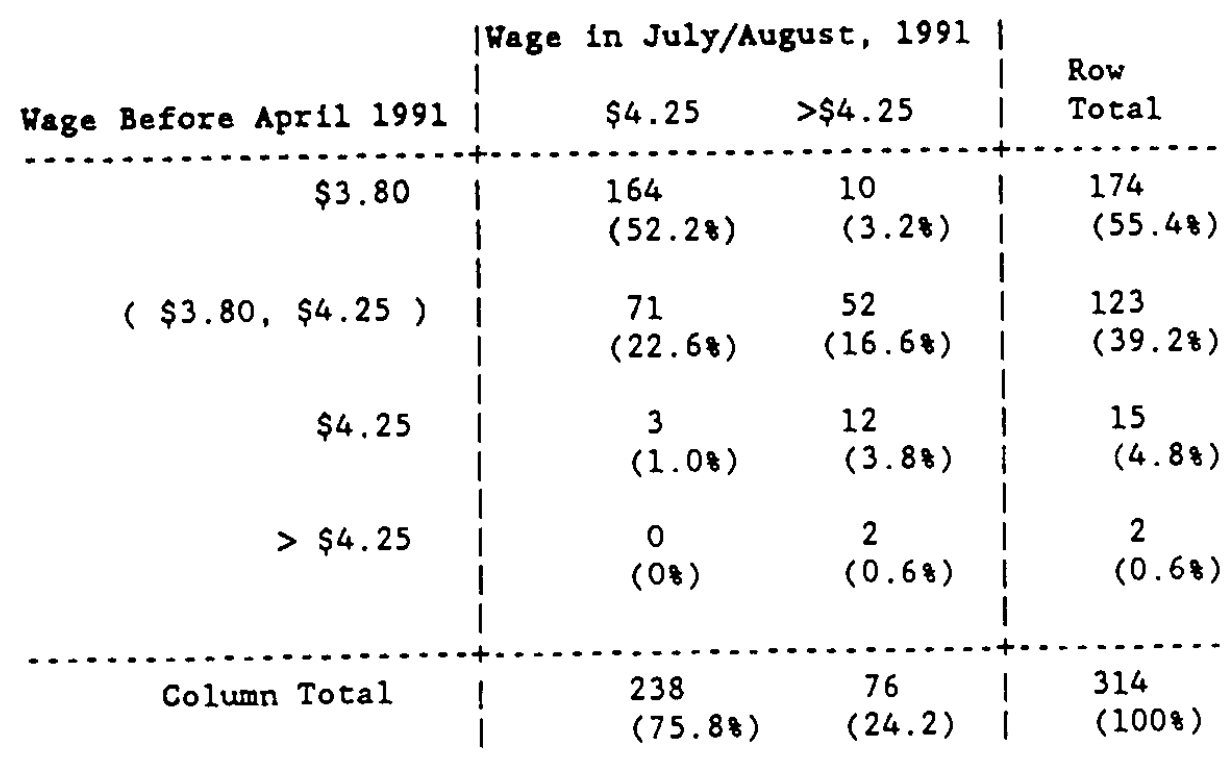

The table gives the number of restaurants in each cell, with the percent of the total underneath in parentheses. One restaurant that reported paying $\$ 3.75$ per hour in April 1991 is recoded as paying $\$ 3.80$ per hour. 
a universe of employers that is likely to be affected by the minimum wage, and that has potential to use the youth subminimum.

\section{Utilization of the Youth Subminimum Wage}

Our initial survey found that a very small percentage of fast food restaurants took advantage of the teenage subminimum wage provisions (see Katz and Krueger, 1991). For example, only $1.8 \%$ of fast food restaurants in our survey used the subminimum wage in December 1990 . This estimate is consistent with Freeman, Gray, and Ichniowski's (1981) finding that only $3 \%$ of students' work hours were covered by the subminimum wage permitted for fulltime students in the late 1970 s. The youth subminimum or "training" wage that we investigate is much easier to use than the full-time student exemption. Notably, the new youth subminimum applies to all teenage workers (not just fulltime students), and requires less cumbersome restrictions on employees' hours. Moreover, under the new law, no additional training is required for the first 90 days, and only a minimal amount of training is necessary if the subminimum is to be used for an additional 90 days.

Our second survey finds that utilization of the youth subminimum increased to $4.8 \%$ of restaurants in July/August 1991 . The small increase in the share of restaurants' utilizing the subminimum wage between 1990 and 1991 is on the margin of being statistically significant $(t=1.90)$. Interestingly, only $34.1 \%$ of 
managers responded that they were unaware of the subminimum wage law in December 1990 , and roughly the same fraction $(31.5 \%)$ responded that they were unaware of the subminimum in the summer of 1991.

In our initial survey of fast food restaurants in 1990 we described the subminimum wage law to managers as a preamble to our question on subminimum wage use. Since we interviewed a random sample of restaurants in 1990, and then interviewed a wider sample in 1991, we can test whether informing managers about the existence of the subminimum wage increased the restaurant's awareness of this option. We find no relationship between whether a manager responds that he or she is aware of the subminimum wage law and whether the restaurant was interviewed in our initial survey. We also find that the firms that were included in the initial survey were slightly more likely to use the subminimum wage $(4.2 \%$ vs. $5.6 \%)$, but that this difference is not statistically significant $(t=0.53)$. Thus informing restaurant managers about the subminimum wage law in 1990 appears to have had no discernable effect on their restaurant's propensity to use the subminimum in 1991.

Another possible reason for the increase in the utilization in the subminimum wage is that the benefit to employers of using the subminimum wage was greater in 1991 than in 1990. First, the gap between the subminimum wage and the minimum wage is greater in absolute value and in percentage terms in 1991 than it was in 1990. ${ }^{10}$ Second, the substantial increase in the minimum wage on April 1, 1991 means that the minimum was 
likely to be farther above the equilibrium wage in the summer of 1991 than in late 1990. Indeed, our survey results suggest that relatively more workers in Texas would accept a fast food job at a subminimum wage if offered. In 1991 , $37.9 \%$ of managers of restaurant that were not using the subminimum wage believed they could "attract qualified teenage workers at a subminimum wage." In 1990 , this figure was just $17.5 \%{ }^{11}$

In spite of the increase in the percentage of managers who believe they can attract teenage workers at a rate below the minimum wage, the majority of respondents said they believed that they could not attract teenage workers a rate below the minimum wage. Because $95 \%$ of these firms were offering new workers an hourly wage rate below $\$ 4.25$ just before the minimum was increased to $\$ 4.25$, it is quite surprising that a large majority of respondents believes that they could not attract workers at a subminimum wage. One explanation for this finding is that restaurants were "supply-constrained" when they offered a wage below $\$ 4.25$, and thus could not attract enough workers at the former wage. Alternatively, managers may feel that relative pay is important to workers, and that workers will not accept jobs if they are paid less than others doing the same work. Workers may also be unwilling to accept jobs at the subminimum wage if it is easier to search for a job paying the new higher minimum wage from unemployment than from employment.

About $20 \%$ of managers at firms that are not using a subminimum wage said they believed it is not fair to use a subminimum wage, and about half of 
managers who offered a response said that they believed that if the subminimum wage could be paid to all workers, not just teenage workers, their restaurant would use the subminimum wage. On the other hand, $23 \%$ of managers responded that the difficulty of applying for the subminimum wage is at least one reason why their restaurant does not offer a subminimum wage. This figure is up from $7.3 \%$ in 1990 . Finally, about one-third of managers who offered a response said that their restaurant would use the subminimum wage if it were easier to administer; for example, if the time limitation or training requirement were eliminated.

To better understand the reasons for the low utilization of the subminimum wage, we have estimated logit models to predict which restaurants use the subminimum wage. In particular, we are interested in whether the gap between the store's starting wage prior to the minimum wage increase in April 1991 and the new minimum wage $(\$ 4.25)$ is positively related to the likelihood it uses the subminimum wage. One would expect that firms will find it more attractive to offer a subminimum wage if the minimum wage forces them to raise their wage by a large amount. Our analysis is based on data collected in the 1991 survey. Table 2 summarizes the logit estimates.

The explanatory variables in the logit models are not very successful at explaining utilization of the subminimum wage. For example, the reported chisquare tests of the hypothesis that the independent variables jointly have no effect have prob-values ranging from .34 to .02 , depending on the model. 
Table 2: Logit Estimates of Subminimum Wage Utilization

\begin{tabular}{|c|c|c|c|}
\hline Variable & (1) & (2) & (3) \\
\hline Intercept & $\begin{array}{l}-3.818 \\
(0.090)\end{array}$ & $\begin{array}{l}-3.836 \\
(1.266)\end{array}$ & $\begin{array}{l}-5.868 \\
(1.644)\end{array}$ \\
\hline $\begin{array}{l}\text { Gap Between Apri1 } \\
\text { Wage and } \$ 4.25\end{array}$ & $\begin{array}{c}2.447 \\
(2.811)\end{array}$ & $\begin{array}{l}2.125 \\
(2.810)\end{array}$ & $\begin{array}{c}1.346 \\
(2.780)\end{array}$ \\
\hline $\begin{array}{l}\text { Company Owned } \\
\text { (1-Yes) }\end{array}$ & - & $\begin{array}{l}-0.852 \\
(0.643)\end{array}$ & $\begin{array}{l}-0.764 \\
(0.656)\end{array}$ \\
\hline $\begin{array}{l}\text { Wendy's } \\
\text { (1-Yes) }\end{array}$ & $\cdots$ & $\begin{array}{l}-0.814 \\
(1.113)\end{array}$ & $\begin{array}{l}-0.867 \\
(1.128)\end{array}$ \\
\hline $\begin{array}{l}\text { Kentucky Fried } \\
\text { Chicken (1-Yes) }\end{array}$ & - & $\begin{array}{l}1.335 \\
(0.656)\end{array}$ & $\begin{array}{l}1.153 \\
(0.661)\end{array}$ \\
\hline $\begin{array}{l}\text { Proportion workers } \\
\text { who are Hispanic }\end{array}$ & -. & $\cdots$ & $\begin{array}{l}3.334 \\
(1.359)\end{array}$ \\
\hline $\begin{array}{l}\text { Proportion workers } \\
\text { who are Black }\end{array}$ & $\cdots$ & $\cdots$ & $\begin{array}{l}2.543 \\
(1.455)\end{array}$ \\
\hline $\begin{array}{l}\text { Proportion of } \\
\text { Teenagers }>.90 \\
(1-\text { yes })\end{array}$ & -- & $\cdots$ & $\begin{array}{c}0.950 \\
(0.853)\end{array}$ \\
\hline P-value for $x^{2}$ & 0.344 & 0.085 & 0.022 \\
\hline
\end{tabular}

standard errors are shown in parentheses. The sample size is 282 , and the mean of the dependent variable is .053 . 
10

Nevertheless, some tentative conclusions can be drawn from the logit estimates. First, although the amount by which a restaurant falls short of the new minimum wage is positively associated with utilization of the subminimum wage, this variable has a statistically insignificant effect. Second, restaurants that have a higher proportion of workers who are hispanic or black are more likely to utilize the subminimum wage. Moreover, these findings for the proportion of minority workers hold up after we include dummy variables for 7 regions of Texas. Third, restaurants that employ a workforce consisting of over $90 \%$ teenage workers are more likely to use the subminimum wage, but this variable does not have a statistically significant effect.

The Effect of Minimum Wage Increases on Compensation

Table 3 presents averages of several measures of compensation, broken down by whether the restaurant started workers at $\$ 3.80$ per hour, between $\$ 3.81$ and $\$ 4.24$ per hour, or at least $\$ 4.25$ per hour just before the minimum wage increase took effect on April 1, 1991. Restaurants that paid the minimum wage $(\$ 3.80)$ prior to April 1991 increased their starting wage by $12 \%$ (46 cents), on average, to just over the new minimum wage $(\$ 4.26)$, by July/August 1991. In contrast, over the same period restaurants that were initially above the new minimum wage increased their starting wage by just $4.6 \%$ ( 20 cents), on average. There are two potential explanations for why firms that were already 
Table 3: Responses to Change in Minimum Wage by Starting Wage Prior to April 1, 1991

\begin{tabular}{|c|c|c|c|c|}
\hline & $\begin{aligned} &( \\
& \text { Sta } \\
&-\$\end{aligned}$ & ting Pay & $\begin{array}{l}\quad(2) \\
\text { Starting Pay Betw. } \\
\$ 3.80 \text { and } \$ 4.25\end{array}$ & $\begin{array}{l}\quad(3) \\
\text { Starting Pay } \\
\geq \$ 4.25\end{array}$ \\
\hline 1. & $\begin{array}{l}\text { Proportion using the } \\
\text { youth subminimum }\end{array}$ & 0.06 & 0.03 & 0.06 \\
\hline 2. & $\begin{array}{l}\text { Average Starting Wage } \\
\text { before April } 1,1991\end{array}$ & $\$ 3.80$ & $\$ 3.93$ & $\$ 4.28$ \\
\hline 3. & $\begin{array}{l}\text { Increase in starting } \\
\text { pay from April } 1 \text { to } \\
\text { December } 1991\end{array}$ & $\$ 0.46$ & $\$ 0.37$ & $\$ 0.20$ \\
\hline 4. & $\begin{array}{l}\text { Proportion maintaining } \\
\text { wage hierarchy }\end{array}$ & 0.16 & 0.33 & $\mathrm{NA}$ \\
\hline 5. & $\begin{array}{l}\text { Proportion with } \\
\text { spillover to workers } \\
\text { earning } \$ 4.50 \text { per hr. }\end{array}$ & 0.09 & 0.29 & 0.60 \\
\hline 6. & $\begin{array}{l}\text { Proportion decreasing } \\
\text { amount of first pay raise }\end{array}$ & 0.05 & 0.03 & 0.00 \\
\hline 7. & $\begin{array}{l}\text { Proportion increasing } \\
\text { time to first pay raise }\end{array}$ & 0.03 & 0.05 & 0.00 \\
\hline 8. & $\begin{array}{l}\text { Proportion that cut } \\
\text { fringe benefits }\end{array}$ & 0.04 & 0.04 & 0.06 \\
\hline 9. & Sample size & 174 & 122 & 17 \\
\hline
\end{tabular}

Proportion maintaining the wage hierarchy is the proportion of restaurants that after April 1, 1991 paid a wage above the restaurant's new starting wage to workers who prior to April 1, 1991 had earned between the restaurant's starting wage and $\$ 3.80$. Proportion with spillover to workers earning $\$ 4.50$ per hr. is the fraction of restaurants that increased the pay of workers earning $\$ 4.50$ once the minimum wage increase took effect. 
paying above the new minimum wage increased their starting wage after the minimum wage increased. First, as Grossman (1983) and Akerlof and Yellen (1990) contend, relative wages may influence work effort so firms already above the minimum wage may adjust their wages to maintain effort levels. Second, it is possible that market forces would have led to a small increase in wages in the fast food industry in Texas even in the absence of the minimum wage increase.

In Table 4 we report estimates of regressions of the log of the starting wage on several independent variables, using data from both waves of our survey. The 1990 and 1991 increases in the minimum wage led to a substantial reduction in the dispersion of starting wages across restaurants. For example, the standard deviation of the log wage decreased from .074 in April 1990, to .046 in December 1990, to .032 in April 1991, and to just .022 in July/August 1991.

The decline in wage dispersion is reflected in the wage regression estimates. For example, the regressions show that before April 1990 company-owned restaurants paid a higher starting wage than franchisee-owned restaurants (see also Krueger, 1991), and that restaurants in areas with a higher unemployment rate have lower wages. However, both of these effects are roughly halved after the minimum wage increased to $\$ 3.80$ (December 1990$)$, and the coefficients continued to shrink after the minimum wage increased to $\$ 4.25$. Similarly, the Kentucky Fried Chicken chain offered a $6 \%(t=3.5)$ higher wage rate than 
Table 4: Log Wage Equations for Starting Wages at Various Dates

\begin{tabular}{|c|c|c|c|c|}
\hline \multirow[b]{2}{*}{ Variable } & \multicolumn{4}{|c|}{ Time Period } \\
\hline & $\begin{array}{c}\text { Before Apr. } 90 \\
\text { (1) }\end{array}$ & $\begin{array}{l}\text { Dec. } 90 \\
\text { (2) }\end{array}$ & $\begin{array}{c}\text { Before Apr } 91 \\
\text { (3) }\end{array}$ & $\underset{(4)}{\text { Aug }} 91$ \\
\hline Intercept & $\begin{array}{l}1.199 \\
(0.090)\end{array}$ & $\begin{array}{c}1.365 \\
(0.063)\end{array}$ & $\begin{array}{c}1.282 \\
(0.030)\end{array}$ & $\begin{array}{l}1.425 \\
(0.020)\end{array}$ \\
\hline $\begin{array}{l}\text { Company Owned } \\
\text { (1-Yes) }\end{array}$ & $\begin{array}{c}0.033 \\
(0.013)\end{array}$ & $\begin{array}{l}0.018 \\
(0.009)\end{array}$ & $\begin{array}{c}0.007 \\
(0.005)\end{array}$ & $\begin{array}{c}0.002 \\
(0.003)\end{array}$ \\
\hline $\begin{array}{l}\text { Wendy's } \\
\text { (1-Yes) }\end{array}$ & $\begin{array}{c}0.024 \\
(0.014)\end{array}$ & $\begin{array}{l}0.015 \\
(0.010)\end{array}$ & $\begin{array}{c}0.011 \\
(0.005)\end{array}$ & $\begin{array}{c}0.002 \\
(0.003)\end{array}$ \\
\hline $\begin{array}{l}\text { Kentucky Fried } \\
\text { Chicken }(1-\text { Yes })\end{array}$ & $\begin{array}{c}0.060 \\
(0.017)\end{array}$ & $\begin{array}{c}0.023 \\
(0.012)\end{array}$ & $\begin{array}{c}0.016 \\
(0.006)\end{array}$ & $\begin{array}{l}0.010 \\
(0.004)\end{array}$ \\
\hline $\begin{array}{l}\text { Log Number of } \\
\text { Employees }\end{array}$ & $\begin{array}{c}0.001 \\
(0.018)\end{array}$ & $\begin{array}{l}-0.010 \\
(0.013)\end{array}$ & $\begin{array}{c}0.008 \\
(0.005)\end{array}$ & $\begin{array}{c}0.004 \\
(0.004)\end{array}$ \\
\hline $\begin{array}{l}\text { City Unemp. Rate } \\
\text { in } 1986\end{array}$ & $\begin{array}{l}-0.576 \\
(0.206)\end{array}$ & $\begin{array}{l}-0.156 \\
(0.143)\end{array}$ & $\begin{array}{l}-0.143 \\
(0.068)\end{array}$ & $\begin{array}{l}-0.054 \\
(0.047)\end{array}$ \\
\hline $\begin{array}{l}\text { Log Population } \\
\text { of City in } 1986\end{array}$ & $\begin{array}{c}0.005 \\
(0.005)\end{array}$ & $\begin{array}{l}0.002 \\
(0.004)\end{array}$ & $\begin{array}{c}0.004 \\
(0.002)\end{array}$ & $\begin{array}{c}0.001 \\
(0.001)\end{array}$ \\
\hline $\mathrm{R}^{2}$ & 0.280 & 0.167 & 0.100 & 0.050 \\
\hline Mean Log Wage & 1.277 & 1.369 & 1.355 & 1.457 \\
\hline SD of Log Wage & 0.072 & 0.046 & 0.032 & 0.022 \\
\hline Sample size & 138 & 138 & 287 & 287 \\
\hline
\end{tabular}

Standard errors are shown in parentheses. 
Burger King before April 1990, and this differential was insignificant by July/August 1991. And the differentials in pay across regions of Texas were virtually eliminated by the increases in the minimum wage. For example, before the April 1990 increase in the minimum wage, restaurants in Dallas paid $8 \%$ more than restaurants in the Rio Grande area, but this gap became insignificant in July/August 1991.

Our survey also collected information on how within-firm wage policy responded to the increases in the minimum wage. In particular, suppose a firm paid $\$ 3.80$ per hour to new workers before April 1990, and then increased its starting wage to $\$ 4.25$. What did such a firm do to the pay of incumbent workers whose wages had risen to a rate of say $\$ 4.00$ ? Our results indicate that 16 percent of firms in this situation increased the wage of the worker earning $\$ 4.00$ to above the new starting wage, and thus maintained their wage hierarchies; the remainder compressed whatever wage differentials existed between long-service workers and new hires. We asked a similar question in the first wave of the survey (e.g., what happened to the earnings of someone whose wage rate rose from $\$ 3.35$ to $\$ 3.50$ once the minimum wage increased to $\$ 3.80$ ?), and found that 41 percent of restaurants maintained their wage hierarchy. Thus firms were much more likely to preserve wage differentials between new workers and long-service workers after the 1990 increase in the minimum wage than after the 1991 increase. Less concern for internal equity in 1991 may result because the rise in the minimum wage to $\$ 4.25$ is likely to 
13

have conferred more rents to infra-marginal workers than the rise to $\$ 3.80$.

A related question is whether firms increased the pay of workers who were already earning above $\$ 4.25$ an hour before the minimum wage increase took effect. We find that firms were less likely to increase these workers' relative earnings than they were to increase the relative earnings of someone earning between $\$ 3.80$ and $\$ 4.25$ (see row 5 of Table 3 ). Not surprisingly, there is less of a spillover effect of the minimum wage increase further up the wage hierarchy.

Finally, we examined whether firms delayed the time until workers receive their first pay raise or reduced the amount of the first raise in response to an increase in the minimum wage. Rows 6 and 7 of Table 3 provide some information on these questions. Although restaurants that were forced to increase their starting wage by the rise in the minimum wage are more likely to delay the first raise they give to workers, and to reduce the amount of the first raise, only a small proportion of firms took these actions. Furthermore, $91 \%$ of restaurants offered at least some fringe benefits to workers, but relatively few restaurants reduced fringes.

Employment Effects of the Minimum Wage

We next examine the effects of recent increases in the Federal minimum wage on employment in the Texas fast-food industry. The conventional 
competitive model of the low-wage labor market predicts that, ceteris paribus, a mandated wage increase from a change in the minimum wage should reduce employment in affected establishments. We examine this issue by comparing employment growth of establishments classified by the likely degree of impact of minimum wage changes. By comparing employment changes of establishments in one industry and state, we eliminate the effects of industry and state shocks to employment that may be correlated over the period examined with the extent of wage changes induced by the minimum wage. Our methodology is similar to the approach used by the U.S. Department of Labor (1959) and Lester (1964) in earlier establishment-based studies of the employment effects of minimum wage laws. ${ }^{12}$

We first analyze the employment effects of the minimum wage increase from $\$ 3.80$ to $\$ 4.25$ in April 1991 using the matched sample of establishments that responded to both our December 1990 and July/August 1991 surveys. For 100 establishments, we have complete data on the number of full-time employees, number of part-time employees, and on the average starting wage for nonmanagement employees both several months before (in December 1990) and several months after (in July/August 1991) the most recent increase in the Federal minimum wage. We measure the likely impact of the minimum wage increase on an establishment's level of employment by the proportional increase required in the firm's starting wage for the firm to minimally comply with the new minimum wage of April 1, 1991. The log minimum wage gap is defined as 
$\min (0, \log (4.25 / W)$ where $W$ is the establishment's starting wage for nonmanagement employees in December 1990. The log minimum wage gap ranges from 0.11 ( $\$ 0.45$ in levels) for firms at the old minimum wage of $\$ 3.80$ to 0 for those already paying at least $\$ 4.25$ prior to the most recent minimum wage increase.

Table 5 presents regression estimates of the effects of wage changes mandated by the minimum wage increase of April 1991 on employment growth from December 1990 to July/August 1991 for our sample of matched establishments. The table presents both the OLS estimates of reduced form models linking employment changes directly to the log minimum wage gap, and two stage least squares estimates of models in which the actual change in the log starting wage is instrumented for by the log minimum wage gap. The first two columns present estimates of equations where the dependent variable is the change in log total employment in bodies (with full-time and part-time workers counted equivalently). The reduced form model indicates that, contrary to the predictions of the conventional competitive labor market model, employment growth was positively related to the size of wage increases mandated by the minimum wage. ${ }^{13}$ The instrumental variables estimates in column (2) show a similar story. The estimates of positive minimum wage effects on employment are statistically significant at the 10 percent level (prob-values of approximately $0.07)$ in both models. The estimates are also moderately large with an elasticity of 1.70 to 1.85 . 
Table 5: Regressions of Employment Changes on Wage Changes Mandated by Increase in Federal Minimum Wage of April 1991

\begin{tabular}{|c|c|c|c|c|}
\hline \multirow[b]{2}{*}{ Variable } & \multicolumn{2}{|c|}{$\begin{array}{l}\text { Change in Log } \\
\text { Employment }\end{array}$} & \multicolumn{2}{|c|}{$\begin{array}{l}\text { Change in Log } \\
\text { FTE Employment in } \\
\text { (Dec. } 1990 \text { - Aug. 1991) }\end{array}$} \\
\hline & $\begin{array}{l}\text { (1) } \\
\text { Reduced Form }\end{array}$ & $\begin{array}{l}(2) \\
2 S L S^{a}\end{array}$ & $\begin{array}{l}\text { (3) } \\
\text { Reduced Form }\end{array}$ & $\begin{array}{l}(4) \\
2 S L S\end{array}$ \\
\hline Intercept & $\begin{array}{c}0.087 \\
(0.372)\end{array}$ & $\begin{array}{c}0.190 \\
(0.366)\end{array}$ & $\begin{array}{l}-0.198 \\
(0.396)\end{array}$ & $\begin{array}{l}-0.051 \\
(0.392)\end{array}$ \\
\hline $\begin{array}{l}\text { Change in } \text { Log }_{\mathrm{b}} \\
\text { Starting Wage }\end{array}$ & -- & $\begin{array}{l}1.734 \\
(0.934)\end{array}$ & $\cdots$ & $\begin{array}{c}2.478 \\
(1.001)\end{array}$ \\
\hline Log MIn. Wage Gap ${ }^{c}$ & $\begin{array}{l}1.850 \\
(0.997)\end{array}$ & -- & $\begin{array}{c}2.643 \\
(1.062)\end{array}$ & - \\
\hline $\begin{array}{l}\text { Company Owned } \\
(1-\text { Yes })\end{array}$ & $\begin{array}{l}-0.051 \\
(0.089)\end{array}$ & $\begin{array}{l}-0.048 \\
(0.090)\end{array}$ & $\begin{array}{l}-0.034 \\
(0.095)\end{array}$ & $\begin{array}{c}0.029 \\
(0.096)\end{array}$ \\
\hline $\begin{array}{l}\text { Burger KIng } \\
\text { (1-Yes) }\end{array}$ & $\begin{array}{c}0.003 \\
(0.094)\end{array}$ & $\begin{array}{c}0.017 \\
(0.093)\end{array}$ & $\begin{array}{l}-0.056 \\
(0.101)\end{array}$ & $\begin{array}{l}-0.036 \\
(0.100)\end{array}$ \\
\hline $\begin{aligned} \text { Kentucky Frled } \\
\text { Chicken (1-Yes) }\end{aligned}$ & $\begin{array}{c}0.113 \\
(0.108)\end{array}$ & $\begin{array}{l}0.089 \\
(0.109)\end{array}$ & $\begin{array}{c}0.034 \\
(0.115)\end{array}$ & $\begin{array}{l}-0.000 \\
(0.117)\end{array}$ \\
\hline $\begin{array}{l}\text { Log Population } \\
\text { of City in } 1986\end{array}$ & $\begin{array}{l}-0.018 \\
(0.029)\end{array}$ & $\begin{array}{l}-0.026 \\
(0.029)\end{array}$ & $\begin{array}{c}0.007 \\
(0.030)\end{array}$ & $\begin{array}{l}-0.005 \\
(0.031)\end{array}$ \\
\hline $\mathrm{R}^{2}$ & 0.055 & - & 0.067 & $\cdots$ \\
\hline S.E. of Regression & 0.363 & 0.363 & 0.387 & 0.389 \\
\hline Sample size & 100 & 100 & 100 & 100 \\
\hline
\end{tabular}

Standard errors are shown in parentheses. The number of full-time equivalents equals full-time employees plus 0.57 times the number of parttime employees. Reduced form models are estimated by OLS.

The log minimum wage gap is used as an instrument for the change in the $\log$ starting wage.

${ }^{b}$ Change in log starting wage of nonmanagerlal employees from December 1990 to July/August 1991 .

$c^{c}$ The $\log$ minimum wage gap equals $\min (0, \log (4.25 / W))$ where $W$ is the starting wage for nonmanagerlal employees in December 1990. 
Columns (3) and (4) of Table 5 present analogous employment change equations with employment measured in full-time equivalent units (FTEs). ${ }^{14}$ The results are even more striking than those using employment in bodies. Employment in FTEs increased by substantially more in establishments with larger mandated wage increases and the estimates are highly statistically significant. A $10 \%$ mandated wage increase is predicted to raise relative employment in FTEs by approximately $25 \%$. The estimated effects of minimum wage induced wage changes on employment presented in Table 5 are not very sensitive to the choice of covariates. For example, if we include seven region dummies along with the covariates in column (4) of Table 5 the coefficient on the change in log starting wage is 2.19 with a standard error of $1.10 .^{15}$

The positive relationship between the wage increase required by the new minimum wage and change in employment is displayed in a scatter diagram in Figure 2. Although some outliers are apparent, the figure illustrates that log employment growth in FTEs was higher on average in establishments with large minimum wage gaps $(\$ 0.45)$ in December 1990 than those with starting wages at or above $\$ 4.25$. Average log employment growth varied from $-.168(n=11)$ for establishments with wages of $\$ 4.25$ or higher in December 1990 , to .058 $(n=23)$ for establishments paying exactly $\$ 4.00$ initially, to $.168(n=40)$ for those paying the old minimum wage of $\$ 3.80$ initially. The corresponding median values for employment growth are: $0, .05$, and .15 , respectively. Because of concern over the possible effects of outliers, we have estimated the 


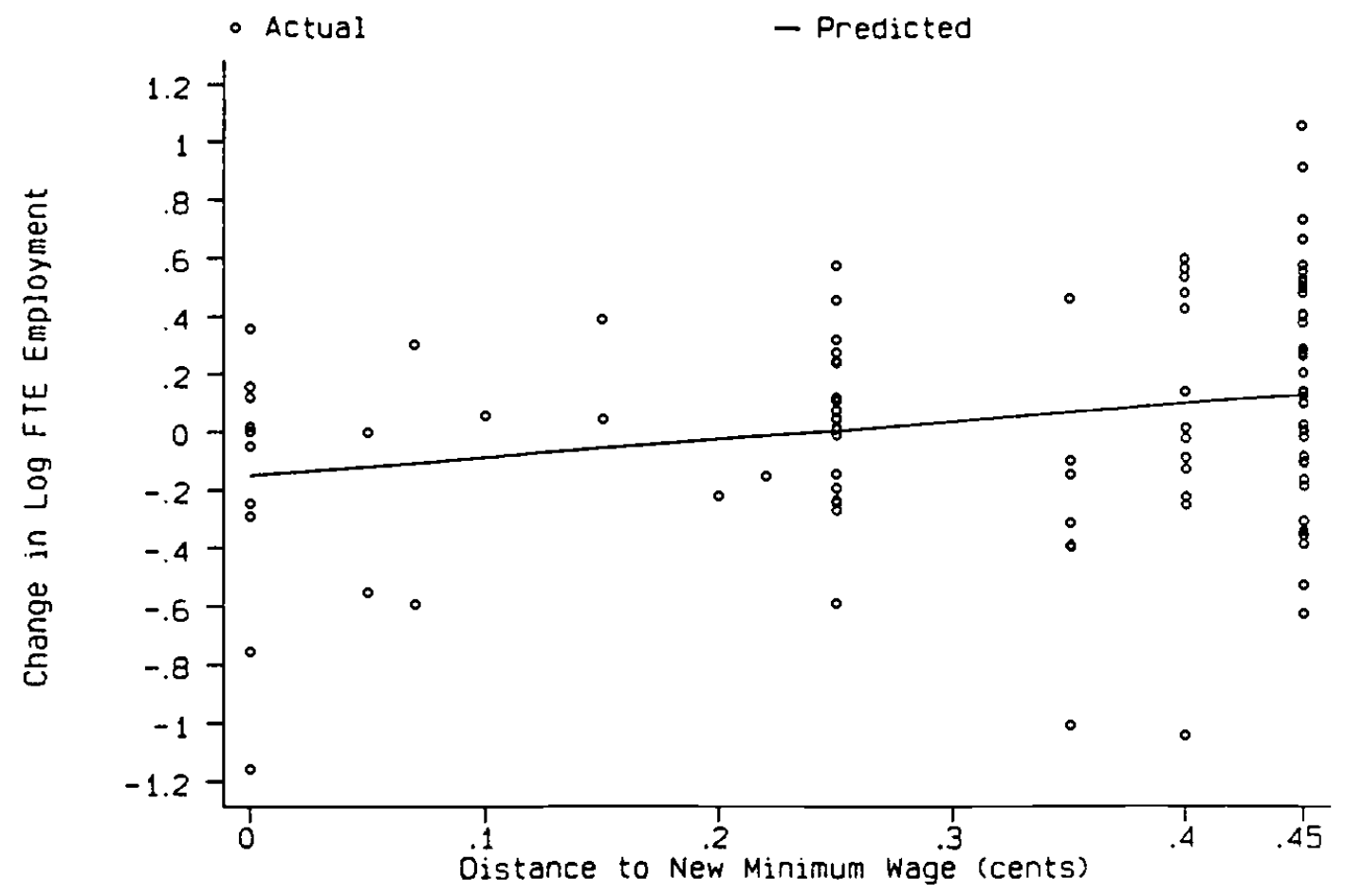

Figure 2 
employment growth models by minimizing the sum of absolute deviations (LAD), in addition to the OLS estimates. The LAD estimates of the employment effects of wage increases are smaller than the OLS estimates but still positive. For example, the coefficient on the log minimum wage gap is 1.16 with a standard error of .55 if the model in Column 3 of Table 5 is by LAD instead of by OLS. ${ }^{10}$ This finding suggests that our positive employment effect is not merely a result of undue influence from outliers.

The estimated positive effects of wage changes on employment are larger if employment is measured by FTEs than by the total number of workers, implying that the share of total employment accounted for by full-time employees increased in establishments with large mandated wage increases relative to other establishments. This finding suggests that minimum wage increases induced firms to substitute full-time for part-time employees. In fact, the overall level of employment (in bodies) per establishment in our entire survey samples remained fairly stable from December 1990 to July/August 1991, but full-time employment per establishment increased from 6.91 to 8.91 and parttime employment per establishment fell from 15.41 to $12.89 .^{17}$

A couple of caveats should be noted in interpreting our finding of a positive effect of the higher minimum wage on employment in the fast food industry. First, our sample is limited to restaurants that were in operation before and after the minimum wage increased. It is possible that the higher minimum wage caused restaurants to close, thereby reducing total employment in the industry. 
Further, the rate of formation of new restaurants might have slowed down because of the minimum wage. Both of these forces might have caused employment to grow at the set of restaurants that remained in operation. Second, although our estimated coefficients for the wage variable in the employment equations are statistically significant, they have relatively large standard errors.

These caveats aside, a model in which the employers of low-wage workers are assumed to have market power and act as monopsonistic buyers of labor (Stigler, 1946; Sullivan, 1989) is potentially consistent with the findings presented in Table 5 and Figure 2. In the standard monopsony model, a binding minimum wage can both increase employment and wages. Our estimates in Table 5 are consistent with a model of monopsony with an elasticity of supply of labor to individual fast-food restaurants ranging from 1.70 to 2.65 . These elasticities indicate a substantial amount of monopsony power in the short run (over an eight month period).

A possible interpretation of this type of monopsony model is that low-wage employers have some degree of monopsony power over their existing employees and do not increase wages to attract further outside employees because internal equity concerns essentially require them to raise the wages of all existing employees to the level of wages of new recruits. The cost of raising the wages of infra-marginal workers outweighs the benefits of attracting new employees with higher starting wages. The responses to both of our surveys of Texas fast- 
food restaurants indicates much employer concern with the fairness of the internal wage structure. The same equity concerns that appear to make establishments reluctant to use the subminimum wage may make them reluctant to raise wages when they have some monopsony power over a subset of workers. The major problem with this monopsony interpretation of our employment findings is that a large degree of monopsony power seems somewhat implausible in the high-turnover labor market of the fast-food industry.

An alternative interpretation is a model with two types of labor with different productivities (e.g. teenagers and adults or part-time and full-time workers) and an internal equity constraint that forces firms to pay both groups the same wage (or limits the wage gap between the groups). Such models have been proposed by Akerlof and Yellen (1990) and Grossman (1983). Firms may choose to pay a low wage and attract workers of type one (teenagers, parttimers) and no workers of type two (adults, full-timers), or perhaps only a small number of type two workers over whom they have some monopsony power. A binding minimum wage could increase the wage to a level that could attract more type two workers. This appears consistent with our finding that wage increases mandated by changes in the minimum wage law appear to be positively related to employment growth and that the growth in employment is concentrated among full-time workers.

Our failure to find conventional negative effects of minimum wage increases on employment is consistent with earlier research using establishment data. 
Lester (1964, pp. 507-27) reviews a series of studies of the effects of the minimum wage increases of March 1, 1956 (from $\$ 0.75$ to $\$ 1.00$ ) on employment changes in establishments in low-wage industries and regions. These studies compared employment growth in specific industries and regions among establishments classified by the percentage increase in average hourly wages mandated by the change in the law. The studies show a wide range of patterns of employment changes classified by minimum wage impact. Lester (1964, pp. 523-24) concludes that, "The statistics ... do not lend much support to the notion that a forced increase in the minimum wage will soon lead to a reduction in a firm's employment in proportion to the relative size of the wage increase."

More recently, Card (1991) has examined the effect of a substantial increase in the state minimum wage in California (from $\$ 3.35$ to $\$ 4.25$ ). He finds that the employment rate of teenagers in California increased both absolutely and relative to the employment rate of teenagers in other "comparable" states after the minimum wage increase took effect. ${ }^{18}$ Thus we conclude that studies based on cross-section comparisons of changes in employment of affected and unaffected groups from changes in minimum wage laws in the United States do not seem to find the conventional negative employment effects apparent from many time-series studies (e.g. Brown, Gilroy, and Kohen, 1983). ${ }^{19}$ Future work should attempt to reconcile the different findings from these alternative methodologies. 
Further information on employment changes is available from our two surveys of Texas fast-food establishments. In the first survey on the effects of the minimum wage increase of April 1990, we asked each firm whether the number of workers on a shift or the number of shifts per day were reduced because of the minimum wage increase. We find little difference in responses between those directly constrained by the minimum wage increase and those already paying starting wages above the now minimum wage prior to April 1990. The vast majority of constrained and unconstrained firms reported not having employment affected by the minimum wage increase. We asked similar question in our July/August 1991 survey of the effects of the April 1991 minimum wage increase. In this case, the response work mildly in favor of the conventional model: $10.5 \%$ of firms constrained by the new minimum (those previously paying under $\$ 4.25$ ) responded that they had reduced the number of nonmanagement workers on a shift since April 1, 1991, whereas six percent of firms initially paying an hourly wage of $\$ 4.25$ or above responded that they had reduced employment since April 1, 1991.

We conclude that our surveys provide little evidence of significant adverse effects of minimum wage increases on employment. Direct measures of employment and wages at the survey dates indicate that employment increased substantially more rapidly from December 1990 to July/August 1991 in firms where the minimum wage increase of April 1991 had a substantial bite than in firms less constrained by the minimum wage increase. Establishment responses 
to questions concerning the direction of changes in employment of nonmanagement employees lead to more ambiguous findings.

\section{Price Effects of the Minimum Wage}

The final issue we examine using our survey data is the effect of the April 1991 minimum wage increase on the prices of meals at fast food restaurants. The conventional model of the effect of a binding minimum wage implies the increase in labor costs should translate into an increase in product prices. To a first order approximation the increase in price should be proportional to minimumwage labor's share of factor costs. In contrast, some monopsony models predict that a small increase in the minimum wage will increase industry employment and output and reduce industry product prices.

In our survey of July/August 1991, we asked about the prices of three standard items at each restaurant: a medium soda, a small order of french fries, and a main course. The main course was a basic hamburger at restaurants in the Burger King and Wendy's chains, and six pieces of chicken in the Kentucky Fried Chicken chain. The survey included questions about both current prices, time since the last price change, and the price in January of 1991.

Table 6 presents estimates of the effects of wage changes induced by the April 1991 increase in the minimum wage on the prices of a full meal, soda, french fries, and a main course. ${ }^{20}$ The dependent variable in each model is the 
Table 6: Two Stage Least Squares Estimates of Price Change Equations

Change in Log Price from January 1 to July/August 1991

\begin{tabular}{|c|c|c|c|c|}
\hline Variable & Full Meal ${ }^{\text {a }}$ & $\begin{array}{l}(2) \\
\text { Soda }\end{array}$ & $\begin{array}{l}(3) \\
\text { Fries }\end{array}$ & Main Course $e^{\text {a }}$ \\
\hline Intercept & $\begin{array}{c}0.092 \\
(0.372)\end{array}$ & $\begin{array}{c}0.118 \\
(0.224)\end{array}$ & $\begin{array}{c}0.164 \\
(0.040)\end{array}$ & $\begin{array}{l}0.038 \\
(0.038)\end{array}$ \\
\hline $\begin{array}{l}\text { Change in } \text { Log }_{\mathrm{b}} \\
\text { Starting Wage }\end{array}$ & $\begin{array}{l}-0.089 \\
(0.133)\end{array}$ & $\begin{array}{l}-0.129 \\
(0.224)\end{array}$ & $\begin{array}{l}-0.367 \\
(0.204)\end{array}$ & $\begin{array}{c}0.121 \\
(0.196)\end{array}$ \\
\hline $\begin{array}{l}\text { Company Owned } \\
\text { (1-Yes) }\end{array}$ & $\begin{array}{l}-0.014 \\
(0.006)\end{array}$ & $\begin{array}{l}-0.033 \\
(0.010)\end{array}$ & $\begin{array}{c}0.001 \\
(0.009)\end{array}$ & $\begin{array}{l}-0.003 \\
(0.008)\end{array}$ \\
\hline $\begin{array}{l}\text { Burger King } \\
\text { (1-Yes) }\end{array}$ & $\begin{array}{l}-0.001 \\
(0.006)\end{array}$ & $\begin{array}{l}-0.017 \\
(0.011)\end{array}$ & $\begin{array}{c}0.006 \\
(0.010)\end{array}$ & $\begin{array}{l}0.020 \\
(0.010)\end{array}$ \\
\hline $\begin{array}{l}\text { Kentucky Fried } \\
\text { Chicken (1-Yes) }\end{array}$ & $\begin{array}{c}0.009 \\
(0.007)\end{array}$ & $\begin{array}{c}0.002 \\
(0.011)\end{array}$ & $\begin{array}{c}0.003 \\
(0.010)\end{array}$ & $\begin{array}{l}0.024 \\
(0.010)\end{array}$ \\
\hline $\begin{array}{l}\text { Log Population } \\
\text { of City in } 1986\end{array}$ & $\begin{array}{l}-0.003 \\
(0.002)\end{array}$ & $\begin{array}{l}-0.004 \\
(0.003)\end{array}$ & $\begin{array}{l}-0.007 \\
(0.003)\end{array}$ & $\begin{array}{l}0.000 \\
(0.003)\end{array}$ \\
\hline 7 Region Dummies & Yes & Yes & Yes & Yes \\
\hline S.E. of Regression & 0.038 & 0.064 & 0.058 & 0.056 \\
\hline Sample size & 266 & 266 & 266 & 266 \\
\hline
\end{tabular}

Standard errors are shown in parentheses. All models are estimated by two stage least squares.

${ }_{A}^{A}$ full meal consists of a soda, french fries, and a main course. A main course consists of a basic hamburger at Burger King and Wendy's, or of six pieces of chicken at Kentucky Fried Chicken.

${ }^{b}$ Change in log starting wage of nonmanagerial employees from April 1991 to July/August 1991. This variable is treated as endogenous and instrumented for using the $\log$ minimum wage gap. The $\log$ minimum wage gap equals min( 0 , $\log (4.25 / W)$ ) where $W$ is the starting wage for nommanagerial employees prior to April 1991. 
log price change from January to July/August 1991 of the relevant item. Each equation is estimated by two stage least squares with the change in log starting wage treated as endogenous and instrumented for by the log minimum wage gap measured in prior to April 1, 1991. The table provides little evidence of relative prices increasing in those establishments with larger mandated wage increases. The results indicate that the price of a full meal tended to decline in restaurants with large mandated wage increases relative to restaurants not much affected by the minimum wage change. The price effects are not large and are fairly imprecisely estimated. The reported equations include region dummies to control for local demand shocks. The basic results are not very different (small and insignificant price effects) when the region dummies or the other covariates are omitted from the models.

\section{Conclusion}

Several tentative conclusions can be drawn from our analysis. First, it appears that relatively few employers use the youth subminimum wage, even in an industry where many employers could probably readily attract teenage workers at a subminimum wage. The subminimum training wage program is experimental and due to expire in on April 1, 1993. Since a small minority of employers has taken advantage of the subminimum wage, we see little grounds for strong support or opposition to the subminimum wage. Second, we have 
found evidence that several fast food restaurants increased wages for workers by an amount exceeding that necessary to comply with the higher minimum wage in 1990. However, there was less of a spillover of the minimum wage to other wages after the 1991 increase in the minimum wage than after the 1990 increase.

Finally, the evidence on employment and price changes does not seem consistent with a conventional view of the effects of increases in a binding minimum wage. Our results indicate that employment increased at firms most affected by the minimum wage increase, while price changes appear to be unrelated to changes in wages resulting from the minimum wage increase. Of course, larger increases in the minimum wage may well result in employment decreases and price increases. Indeed, Castillo-Freeman and Freeman (1992) find that the relatively high minimum wage in Puerto Rico has resulted in substantial employment losses. Under certain conditions, monopsony models predict that a small increase in the minimum wage leads to an increase in employment, whereas a large increase in the minimum wage leads to a decrease in employment.

The behavior that we have documented in this article seems difficult to explain with the standard model that economists use to evaluate the impact of a minimum wage. It would be useful to know if our empirical findings hold up in other establishment-based analyses of the impact of the minimum wage. ${ }^{21}$ Finally, since our analysis is based on a subset of employers that remained in 
continuous operation before and after an increase in the minimum wage, it would be useful to study whether increases in the minimum wage lead to an increase in the failure rate of existing firms and a reduction in the birth rate of new firms. 
References

Akerlof, George, and Janet Yellen. 1990. "The Fair-Wage Effort Hypothesis and Unemployment." Quarterly Journal of Economics, Vol. 105, No. 2 (May). pp. 255-84.

Brown, Charles, Curtis Gilroy, and Andrew Kohen. 1983. "Time Series Evidence on the Effect of the Minimum Wage on Youth Employment and Unemployment." Journal of Human Resources, Vol. 18, No. 1 (Winter), pp. 3-31.

Bureau of National Affairs. 1985. "Employee Relations in the Fast Food Industry." Supplement to Retail/Services Labor Report. Washington, D.C.

Card, David. 1991. "Do Minimum Wages Reduce Employment? A Case Study of California, 1987-89." NBER Working Paper No. 3710.

Card, David. 1992. "Using Regional Variation in Wages to Measure the Effects of the Federal Minimum Wage." Unpublished paper, Princeton University.

Castillo-Freeman, Alida and Richard B. Freeman. 1992. "When the Minimum Wage Really Bites." In G. Borjas and R. Freeman, eds., The Economic Effects of Immigration in Source and Receiving Countries. Chicago: University of Chicago Press, forthcoming.

Charner, Ivan and Bryna S. Fraser. 1984. Fast Food Jobs. Washington, D.C.: National Institute for Work and Learning.

Cullen, Donald E. 1961. Minimum Wage Laws. Bulletin 43, New York School of Industrial and Labor Relations, Cornell University, Ithaca, New York, February.

Freeman, Richard, Wayne Gray, and Casey E. Ichniowski. 1981. "Low Cost Student Labor: The Use and Effects of the Subminimum Wage Provisions for Full-Time Students." Report of the Minimum Wage Study Commission, Vol. 5. Washington, D.C.: U.S. GPO, pp. 305-335.

Grossman, Jean B. 1983. "The Impact of the Minimum Wage on other Wages." Journal of Human Resources, Vol. 18, No. 3 (Summer), pp. 259-378.

Katz, Lawrence F., and Alan B. Krueger. 1991. "The Effect of the New Minimum Wage in a Low-wage Labor Market." Proceedings of the Forty-Third Annual Meetings (Washington, D.C., Dec. 28-30, 1990). Madison, Wis.: Industrial Relations Research Association, pp. 254-266. 
Krueger, Alan B. 1991. "Ownership, Agency and Wages: An Examination of Franchising in the Fast Food Industry." Quarterly Journal of Ecenomics, Vol. 106, No. 1 (February), pp. 75-101.

Lester, Richard A. 1964. The Economics of Labor. 2nd Edition. New York: Macmillan.

Love, John. 1986. McDonald's: Behind the Golden Arches. New York: Bantam Books.

Spriggs, William, David Swinton and Michael Simmons. 1992. "The Effects of Changes in the Federal Minimum Wage: Restaurant Workers in Mississippi and North Carolina." Unpublished paper, Economic Policy Institute, Washington D.C.

Stigler, George J. 1946. "The Economics of Minimum Wage Legislation." American Economic Review. Vol. 36, No. 3 (June), pp. 358-365.

Sullivan, Daniel G. 1989. "Monopsony Power in the Market for Nurses." Journal of Law and Economics. Vol. 32, No. 4 (October), pp. S135-S178.

U.S. Bureau of the Census. 1988. County and City Data Book, 1988. Washington, D.C.: U.S. GPO.

U.S. Department of Labor. Wage and Hour and Public Contracts Divisions. 1959. Studies of the Economic Effects of the $\$ 1$ Minimum Wage, Effects in Selected Low Wage Industries and Localities. Washington, D.C.: U.S. GPO. 
</ref_section> 
Notes

1. We are grateful to David Card for providing these statistics to us. The statistics are based on data from the Current Population Survey.

2. The state minimum wage in Texas is $\$ 3.35$ per hour, and there is no provision for a subminimum. Therefore, the Texas state minimum wage law is irrelevant for jobs that are covered by the federal minimum wage. In some other states, the state minimum wage is high enough to prevent employers from utilizing the federal youth subminimum wage.

3. Indeed, Love (1986) estimates that 1 in 15 workers obtained their first job from McDonald's! Although we're not sure whether this estimate is accurate, it must undoubtedly be the case that many young workers obtain their first job in the fast food industry.

4. Copies of the 1990 and 1991 questionnaires (including mean responses) are available from the authors upon request.

5. Burger King, Kentucky Fried Chicken and Wendy's are the second, third and fourth largest restaurant chains nationwide. We initially intended to also include McDonald's, the nation's largest chain. But because none of the McDonald's restaurants would respond to our pre-test survey we dropped them from our sample.

6. Of the restaurants listed in the phone book, 25 were unreachable because of closings, transcription errors or some other reason for a disconnection, and 10 were wrong numbers.

7. Although there may be some concern about possible differences between respondents and nonrespondents, our tabulations did not reveal any systematic differences between restaurants that responded on the first call and those that required at least one follow-up phone call before responding.

8. Restaurants that paid a higher wage in December 1990 were more likely to respond in the second wave of the survey, but the relationship between wage and attrition was statistically insignificant. If low-wage restaurants were more likely to close because of the increase in the minimum wage, we would expect this pattern of attrition.

9. We use the wage of part-time workers if the restaurant reports a part-time wage, and the wage of full-time workers if the part-time wage is missing. In 1991, all restaurants in the sample that provided wage information paid the same wage to full- and part-time workers. In April 1990, $97 \%$ of restaurants paid the same wage to full- and part-time workers, and in December $199093 \%$ 
of restaurants paid the same wage to full- and part-time workers. Table 1 includes information on all the restaurants that provided data on starting wages. In each subsequent table, we use the maximum possible sample of restaurants that have information on all the relevant variables for that table.

10. Although the subminimum wage is set at $85 \%$ of the minimum wage, the subminimum was fixed at $\$ 3.35(11.8 \%$ below the minimum wage) for the first increase in the minimum wage.

11. Another possible reason for this trend is that the supply of teenage employees to fast food restaurants is likely to be more plentiful in the summer (when the 1991 survey was conducted) than in the winter (when the 1990 survey was conducted).

12. See also Cullen (1961) for a thoughtful evaluation of the evidence on minimum wage effects based on the early literature.

13. At the suggestion of a referee, we also estimated specifications that included the proportionate gap between the minimum wage and the restaurant's starting wage just prior to the April 1991 increase in the minimum wage (i.e, proportionate increase to reach $\$ 3.80$ ). This new variable could be thought of as a lag of the minimum wage gap that we have included. The log minimum wage gap was highly correlated both periods. Nevertheless, both log minimum wage gaps were estimated to have a positive effect if they were included together in the model, and the coefficient was larger for the December 1991 log wage gap.

14. The number of full-time equivalents equals the number of full-time employees plus 0.57 times the number of part-time employees. This definition is based on our tabulations of data from the 1982-83 survey of employees in the fast-food industry conducted by the National Institute for Work and Learning (NIWL). We find in this data a ratio of average weekly hours of part-time to those of full-time employees of 0.57 . See Charner and Fraser (1984) for a discussion of the NIWL survey.

15. One could argue that region dummy variables should be included to capture possible correlations between local labor market shocks during our sample period and initial wage levels.

16. The standard error was estimated by bootstrapping the model, using 50 replications.

17. We note, however, that seasonality in full-time employment may also account for the relative increase in full-time employment between December 1990 and August 1991. 
18. Card (1992) similarly fails to find conventional negative employment effects of the 1990 federal minimum wage increase in an analysis that uses regional variation in the likely impact of the increase on the low-wage labor market.

19. A comparison of employment changes across industries by the likely degree of impact of the minimum wage does seem to follow the negative correlation predicted by a standard competitive model for the large increases in the minimum wage in Puerto Rico studied by Castillo-Freeman and Freeman (1992).

20. A full meal, for our purposes, consists of a soda, french fries, and a main course.

21. We note that a preliminary analysis of a new data set on restaurants in Mississippi and North Carolina by Spriggs, Swinton and Simmons (1992) finds results generally similar to ours. 